\title{
Chlorambucil and cyclosporine A in Brazilian patients with Behçet's disease uveitis - A retrospective study
}

\author{
Clorambucil e ciclosporina A em pacientes brasileiros com doença de Behçet \\ e uveíte - Estudo retrospectivo
}

\author{
Juliana Marques Zaghetto ${ }^{1}$ \\ Mirian Mina Yamamoto ${ }^{2}$ \\ Murilo Barreto Souza ${ }^{3}$ \\ Felipe Theodoro Bezerra \\ Gaspar Carvalho da Silva ${ }^{4}$ \\ Carlos Eduardo Hirata ${ }^{5}$ \\ Edilberto Olivalves ${ }^{6}$ \\ Joyce Hisae Yamamoto ${ }^{7}$
}

\begin{tabular}{|c|}
\hline ABSTRACT \\
\hline 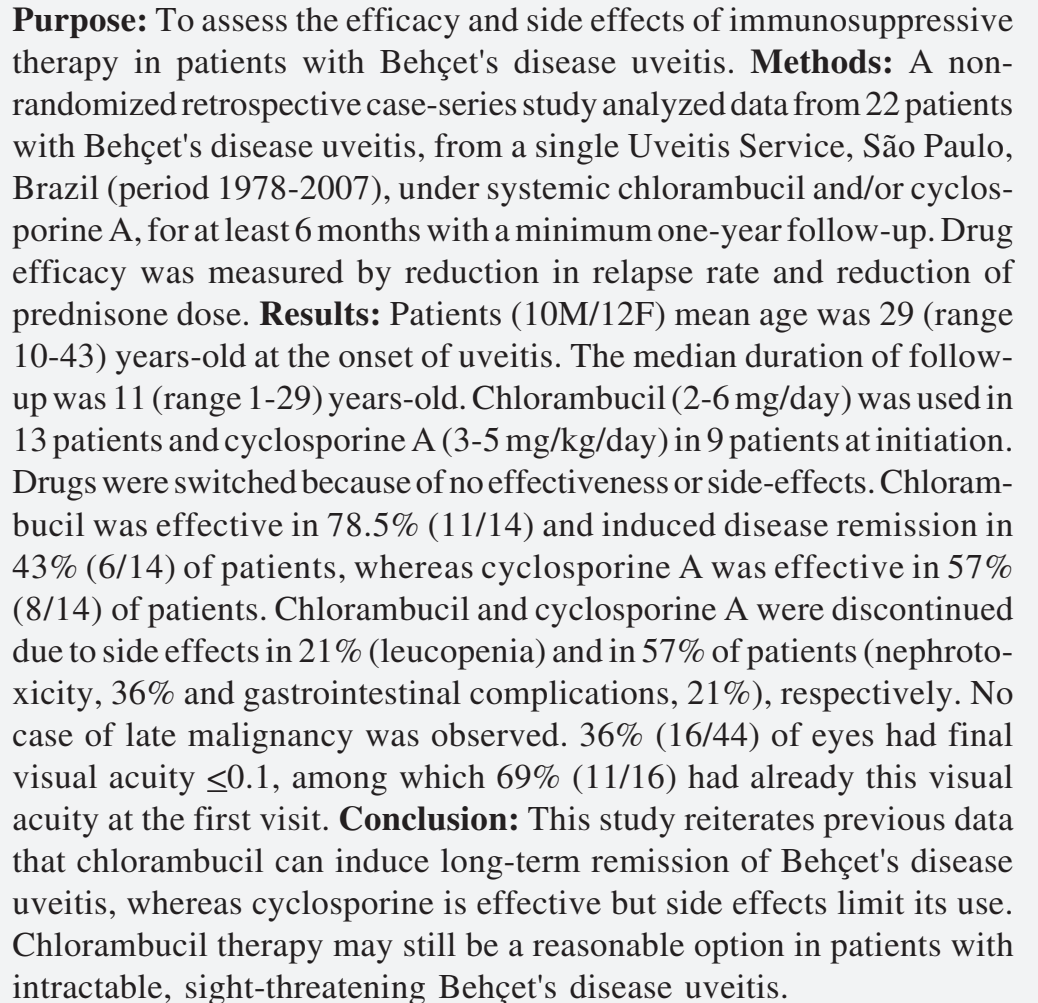 \\
\hline
\end{tabular}

Keywords: Behçet syndrome; Immunosuppressive agents/therapeutic use; Chlorambucil/ therapeutic use; Cyclosporine/therapeutic use; Uveitis/therapy; Retrospective studies

\section{INTRODUCTION}

Behçet's disease is a chronic, relapsing, multisystemic idiopathic inflammation characterized by recurrent oral aphthous ulcers, skin lesions, genital ulcers and ocular lesions. It is most prevalent between the second and fourth decades of life. This ubiquitous disorder exhibits a distinct geographic variation and is found predominantly between East Asia and the Mediterranean basin ${ }^{(1)}$. In Brazil it accounts for $3 \%$ of uveitis cases ${ }^{(2)}$. The disease is associated with the major histocompatibility complex antigen HLA-B51, mainly in areas along the Silk Road and Japan ${ }^{(3)}$. The 
frequency of ocular involvement in patients varies between $50-70 \%$ in different populations ${ }^{(1)}$. Ocular disease may be the initial manifestation of the disease in approximately onefifth of cases. Although the course of the disease is usually benign in the absence of vital organ involvement, the longterm prognosis for vision is poor if the retina is involved by recurrent obliterative retinal vasculitic attacks. Indeed, it is estimated that $30 \%$ of patients loose useful visual acuity $(>0.1)$ in 10 years after the onset of ocular symptoms, this holding true especially regarding Turkish and Japanese patients $^{(4-6)}$.

Systemic immunosuppressive treatment is the standard of therapy for ocular inflammation in Behçet's disease. Corticosteroids were used widely in the 1960 s to treat this disease. Chlorambucil was introduced in Behçet's disease in 1970 by Mamo and was successfully used in its treatment ${ }^{(7-8)}$. Concern regarding serious side effects, such as the development of malignancy, bone marrow aplasia and infertility, limited its widespread use ${ }^{(9)}$. Cyclosporine was widely tested in the 1980s and soon became one of the preferred immunosuppressant in Behçet's disease ${ }^{(10-11)}$. Recently some authors conducted a reappraisal of the use of short-term/high-dose chlorambucil in sight-threatening uveitis and suggested the sustained remission after using this regimen may make it a preferred treatment option for patients with intractable, sightthreatening uveitis ${ }^{(12)}$.

The present retrospective study aimed to determine the effectiveness of chlorambucil and cyclosporine A and the incidence of side effects in Brazilian patients with Behçet's disease uveitis in the "pre-biological agents" period.

\section{METHODS}

This retrospective non-randomized study analyzed the medical records of 22 patients with Behçet's disease uveitis under systemic immunosuppressant, from the Uveitis Service, Department of Ophthalmology, Hospital das Clínicas, University of São Paulo School of Medicine (HCFMUSP), São Paulo, Brazil, from 1978 to 2007. All patients met the Behçet's Disease Research Committee of Japan diagnostic criteria ${ }^{(13)}$. Data collection for the purpose of the study was approved by the institutional review board.

Demographic, ocular and systemic data were obtained including ocular disease activity findings ${ }^{(14)}$ (anterior chamber cells, vitreous haze, retinal vasculitis, macular edema and optic neuritis), ocular complications, use of immunosuppressant (efficacy and side effects) and irreversible loss of useful vision $(\leq 0.1)$ over the follow-up period. HLA-B typing was performed in 14 patients by the microlymphocytoxicity technique (C-Six Diagnostics, Mequon, WI, and One Lambda, Inc., Los Angeles, CA) and by polymerase chain reaction with sequence-specific oligonucleotides (DynalRELItm SSO HLA-B-test, Dynal Biotech, Bromborough, UK) ${ }^{(15)}$.
Patients with recurring severe uveitis attacks due to Behçet's disease were treated with oral corticosteroid (40-60 mg/day) combined with a systemic immunosuppressive agent. After a baseline clinical and laboratorial evaluation, patients were informed about the benefits and risks of the drug. Available immunosuppressive drugs changed during the study period of 29 years. Cyclosporine A (CsA) became freely available for Brazilian patients by Brazilian Ministry of Health in 1998. Thus, chlorambucil (CLB) and cyclosporine differed regarding the period of indication; before 1998 the drug of choice was chlorambucil, and after that cyclosporine. In case of intolerance or treatment failure, drugs were substituted. Chlorambucil initial dosage was $2 \mathrm{mg}$ /day with gradual increase to $6 \mathrm{mg} /$ day accordingly to disease activity and absence of side-effects. Dosage was reduced to half when white blood cell count fell to $4.000 / \mathrm{mm}^{3}$ and discontinued when the peripheral cell count fell below $3.500 / \mathrm{mm}^{3}$. Initial cyclosporine A dosage varied from 2 to $6 \mathrm{mg} / \mathrm{kg} / \mathrm{day}$; renal function was monitored by serum creatinine and 24 hour-creatinine clearance. A $30 \%$ drop of glomerular filtration rate from the baseline was indicative for dose reduction. CsA though levels were monitored every 2-3 months to keep a stable whole-blood therapeutic range $(100-300 \mathrm{ng} / \mathrm{ml})$. All patients were followed up at monthly visits (ocular and systemic evaluations) and examined for drug-related side effects for at least one year before being included in this study. Monthly laboratory workup included complete blood count, kidney function tests, liver function tests, serum glucose, serum lipids levels, Westergreen erythrocyte sedimentation rate.

All patients on immunosuppressant for longer than 6 months and with a minimum one-year-follow-up were included in the analysis of drug efficacy. Grading of efficacy of treatment was assessed according to the relapse rate before and during the immunosuppressant as follows ${ }^{(14)}$ :

1. Effective: no relapse or at least two relapses less than before treatment per year

2. Mildly effective: one relapse less than before treatment per year

3. No response: no change in relapse rate per year

4. Worsening: more relapses per year than before after treatment.

Another outcome measured was reduction in the prednisone dose to $10 \mathrm{mg}$ per day or less ${ }^{(16)}$. Disease remission was defined as inactive disease for at least 3 months after discontinuing all systemic treatment for eye disease ${ }^{(16)}$. Several patients switched drugs and efficacy was evaluated according to the period that each drug was used.

Data regarding clinical aspects of ocular disease and efficacy of individual drugs were analyzed using association tests (Likelihood- ratio test, Fisher's exact test and Chi-square test). $P$-values $<0.05$ were considered statistically significant. Data analysis and statistical tests were done using SPSS 13.0 (SPSS Science, Chicago, IL, USA). 


\section{RESULTS}

Twenty-two patients (44 eyes) with Behçet's disease uveitis under systemic immunosuppressant were included in this nonrandomized retrospective case-series study. Demographic data and clinical manifestations are shown in tables 1 and 2.

As first choice immunosuppressive therapy, chlorambucil was used in 13 patients (59\%), while cyclosporine A was used

\begin{tabular}{|c|c|}
\hline \multicolumn{2}{|l|}{ Description } \\
\hline $\mathrm{N}$ & 22 \\
\hline Age at uveitis onset, yrs, mean $\pm S D$ & $29.6 \pm 7.3$ \\
\hline Gender male, n (\%) & $10 \quad(45.5)$ \\
\hline Bilateral, n (\%) & $22(100.0)$ \\
\hline HLA-B51, n/total (\%) & $8 / 14 \quad(57.1)$ \\
\hline \multicolumn{2}{|l|}{ Extraocular manifestations, $\mathrm{n}(\%)$} \\
\hline Recurrrent oral ulcer & $22(100.0)$ \\
\hline Genital ulcer & $16 \quad(72.7)$ \\
\hline Skin lesion & $16 \quad(72.7)$ \\
\hline Arthritis & $9 \quad(40.9)$ \\
\hline Deep vein thrombosis & $2 \quad(9.1)$ \\
\hline Central nervous system involvement & (0) \\
\hline Follow-up period, yrs, median (range) & $11(1-29)$ \\
\hline
\end{tabular}

in 9 patients (41\%). Five patients switched from chlorambucil to cyclosporine A and one patient switched from cyclosporine A to chlorambucil due to side effects. Chlorambucil was effective regarding flare-up in 11 patients $(78.5 \%)$, in 3 patients $(21.5 \%)$ there was no response. Prednisone could be reduced in 11 patients $(78.5 \%)$. Follow-up of patients under chlorambucil was 13.4 years (median, range 4.4-29.5 yrs) with total cumulative dosage of $3420 \mathrm{mg}$ (median, 360-8280 mg) and duration of treatment of 28 months (median, 6-48 mo). Six patients $(43 \%)$ had remission of the disease even after 11.6 (range 4-20) years. Of the 14 patients who used cyclosporine A ( $3-5 \mathrm{mg} / \mathrm{kg} /$ day), in $8(57.2 \%)$ was effective regarding flareup, $2(14.3 \%)$ mildly effective, $4(28.5 \%)$ had no response. Prednisone was reduced in half of the 14 patients who used it. Remission occurred in 1 patient (7\%) who used chlorambucil as first choice. Disease flared-up while reducing CsA dose in 5 patients (35.7\%). Follow-up of patients under cyclosporine A was 6.2 years (median, 1-13.6 yrs), initial CsA dosage was $3.7 \mathrm{mg} / \mathrm{kg} /$ day (median, $1.5-5.8 \mathrm{mg} / \mathrm{kg} /$ day) and duration of treatment was 32 months (median, 7-70 mo). Clinical and therapeutical characteristics of each patient with Behçet's disease uveitis are described in table 3.

Nine patients (64.2\%) who used chlorambucil had side effects. The most common were gonadal dysfunction in 5 patients $(35.7 \%)$, leucopenia in $4(28.5 \%)$ and infection in $2(14.2 \%)$. Of the 14 patients who used cyclosporine A, 10 (71.4\%) had side effects such as nephrotoxicity in $5(35.7 \%)$,

\begin{tabular}{|c|c|c|c|c|c|c|c|}
\hline & $\mathbf{N}$ & $(\%)$ & $\mathbf{N}$ & $(\%)$ & $\mathbf{N}$ & $(\%)$ & p \\
\hline \multicolumn{8}{|l|}{ Type of uveitis } \\
\hline Anterior & 2 & $(4.3)$ & 2 & $(10.0)$ & 0 & (0) & $0.191^{\mathrm{a}}$ \\
\hline Intermediate & 0 & (0) & 0 & (0) & 0 & (0) & \\
\hline Posterior & 10 & $(22.7)$ & 4 & $(20.0)$ & 6 & $(25.0)$ & \\
\hline Iridocyclitis & 29 & $(65.9)$ & 14 & $(70.0)$ & 15 & $(62.5)$ & $0.601^{\mathrm{b}}$ \\
\hline Vitritis & 26 & $(59.1)$ & 10 & $(50.0)$ & 16 & $(66.6)$ & $0.263^{b}$ \\
\hline Retinal vasculitis & 23 & $(52.3)$ & 11 & $(55.0)$ & 12 & $(50.0)$ & $0.741^{\mathrm{b}}$ \\
\hline Macular edema & 5 & $(11.4)$ & 3 & $(15.0)$ & 2 & ( 8.3) & $0.646^{c}$ \\
\hline Hypopion & 1 & ( 2.2) & 1 & $(5.0)$ & 0 & (0) & $0.455^{c}$ \\
\hline Ocular hypertension & 5 & $(11.3)$ & 0 & $(0)$ & 5 & $(20.8)$ & $0.530^{c}$ \\
\hline Disk and/or retinal neovascularization & 3 & $(6.8)$ & 1 & $(5.0)$ & 2 & $(8.3)$ & $>0.999^{c}$ \\
\hline Retinal detachment & 2 & $(4.5)$ & 2 & $(10.0)$ & 0 & $(0)$ & $0.201^{c}$ \\
\hline Branch vein occlusion & 1 & ( 2.2) & 1 & $(5.0)$ & 0 & (0) & $0.455^{c}$ \\
\hline Epiretinal membrane & 1 & ( 2.2) & 0 & $(0)$ & 1 & $(4.1)$ & $>0.999^{c}$ \\
\hline Phthisis bulbi & 1 & ( 2.2) & 0 & (0) & 1 & $(4.1)$ & $>0.999^{c}$ \\
\hline Poor visual acuity $(<0.1)$ & 16 & $(36.3)$ & 5 & $(25.0)$ & 11 & $(45.8)$ & $0.153^{b}$ \\
\hline At presentation & 18 & $(40.9)$ & 8 & $(40.0)$ & 10 & $(41.6)$ & $0.911^{b}$ \\
\hline
\end{tabular}




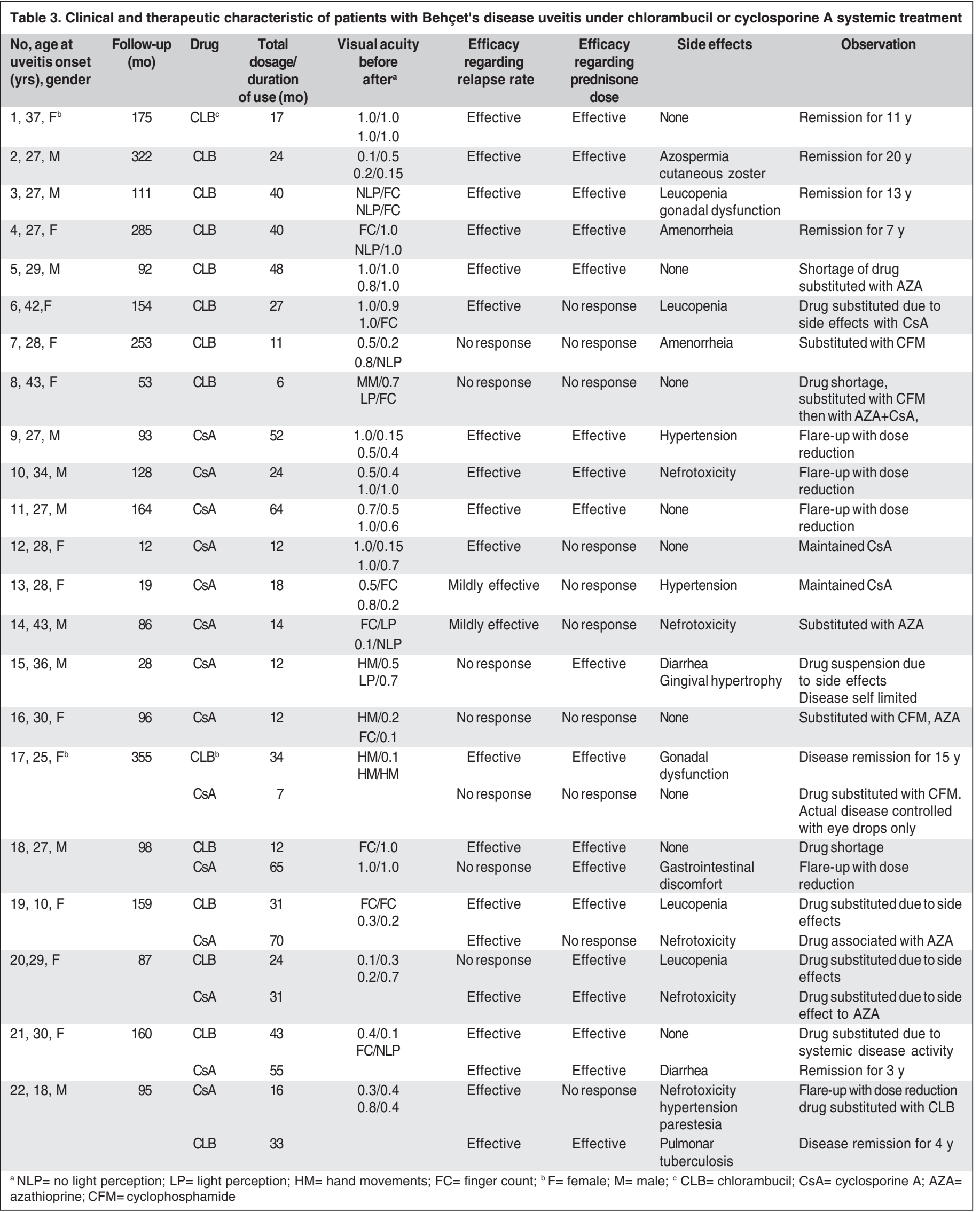


gastrointestinal complication in 3 (21.4\%), hypertension in 3 $(21.4 \%)$, severe gingival hypertrophy and paraesthesia in 1 each (7.1\%). Efficacy and side effects of each immunosuppressant are described in table 4 . The median time before occurrence of gonadal dysfunction was 36 (range 24-48) months; leucopenia, 33 (range 23-42) months; infection, 12 (range 4-20) months; nephrotoxicity, 14 (range 9-48) months; gastrointestinal complication, 30.6 (range 1-51); hypertension, 7.5 (range 1-24) months; gingival hypertrophy, 12 months and paraesthesia, 14 months.

There were 16 eyes (36\%) with final visual acuity worse or equal to 0.1 , among which 11 (69\%) had already this visual acuity at the first visit (Table 2). The reasons for visual acuity deterioration were: optic atrophy in $6(37.5 \%)$ eyes, cataract development in $5(31.2 \%)$, retinal damage due to severe retinal vasculitis in $3(18.7 \%)$, macular hole in $1(6.3 \%)$ and phthisis bulbi in $1(6.3 \%)$. Median time for each ocular complication to be detected was as follows: cataract, 63 (range 3-263) months; macular abnormalities, 73 (range 9-301) months; optic atrophy, 225 (range 42-263) months; ocular hypertension, 48 (range 27253) months; retinal neovascularization, 39 (range 11-49) months; and epiretinal membrane 87 months. Branch retinal vein occlusion and phthisis bulbi were observed at either presentation or early during the follow-up.

\section{DISCUSSION}

This non-randomized retrospective case series of patients with Behçet's disease uveitis treated in a single center with either chlorambucil or cyclosporine A over 29 years reiterates previous data that chlorambucil can induce long-term remission of Behçet's disease. Chlorambucil and cyclosporine efficacy was measured by reduction in relapse rate and reduction of prednisone dose. Both drugs were partially effective but, as expected, associated with a high incidence of side effects. Few patients with good vision lost it under the immunosuppressive regimes reinforcing the aphorism that those who do badly usually start badly. Late malignancy is of great concern after therapy with an alkylating agent and it is associated with total dose and duration of therapy.

Chlorambucil's use in Behçet's disease uveitis dates from 1970 on and it is effective in controlling ocular inflammation, in ameliorating systemic symptoms and in inducing longterm remission in about $60 \%$ to $100 \%$ of patients ${ }^{(8,17-18)}$. Nevertheless, its serious long-term side effects made it not the first line of therapy in Behçet's disease ${ }^{(19)}$. The most dreaded potential side effects of chlorambucil are a dosagerelated increase in the risk of malignancy and bone marrow aplasia $^{(9,20-21)}$. In earlier reports on chlorambucil ${ }^{(7-8,18)}$, treatment duration varied from 3 to 17 months, dosage varied from 5 to $24 \mathrm{mg} /$ day with a follow-up no longer than 6 years. The cumulative dose ranged from 1710 to $2250 \mathrm{mg}^{(18)}$. In more recent reports ${ }^{(12,22)}$, favorable results were observed after short-term ( 7 to 40 weeks), high-dosage (mean maximum daily dose of $20 \mathrm{mg} / \mathrm{day}$, range $10-30 \mathrm{mg} /$ day) courses of chlorambucil with a median follow-up of 46 months and no relevant side effects. The cumulative dose of chlorambucil ranged from $392 \mathrm{mg}$ to $5200 \mathrm{mg}$ with an average total dose of $1416 \mathrm{mg}^{(12)}$. In the present retrospective study, long-term (median 28 months, range 6-48 months) chlorambucil (median dose $4 \mathrm{mg} /$ day, range $2-6 \mathrm{mg} /$ day) was effective in $78.5 \%$ of the patients and disease remission was observed in $43 \%$ of the patients. The cumulative dosage was similar or even higher than previous reports. In this case-series, $64.2 \%$ of patients presented some form of side effect,

Table 4. Efficacy and adverse effects of systemic immunosuppressant in patients with Behçet's disease uveitis (Hospital das Clínicas, University of São Paulo School of Medicine, Brazil, 1978-2007)

\begin{tabular}{|c|c|c|}
\hline & Chlorambucil & Cyclosporine \\
\hline Effective & $11(78.5)$ & $8(57.2)$ \\
\hline No response & $3(21.5)$ & $4(28.5)$ \\
\hline \multicolumn{3}{|c|}{ Efficacy regarding prednisone reduction $\left(p=0.115^{b}\right)$} \\
\hline Effective & $11(78.5)$ & $7(50.0)$ \\
\hline Gonadal dysfunction & $5(35.7)$ & \\
\hline Leucopenia & $4(28.5)$ & \\
\hline Infection & $2(14.2)$ & \\
\hline Nephrotoxicity & & $5 \quad(35.7)$ \\
\hline Gastrointestinal complication & & $3(21.4)$ \\
\hline Hypertension & & $3(21.4)$ \\
\hline
\end{tabular}


among which $21 \%$ needed to change therapy. No patient presented malignancy over the long follow-up period (median 13.4 yrs). Other observed side effects were gonadal dysfunction, leucopenia and infection, as described in the literature $^{(20)}$. Since work-up for gonadal dysfunction was not routinely performed, this side effect were underestimated in this series.

Cyclosporine was first introduced to treat bilateral and sight-threatening uveitis, including Behçet's disease, in the 1980s by Nussenblatt ${ }^{(10)}$. After that, most authors switched from cytotoxic drugs to cyclosporine $\mathrm{A}^{(11,23)}$. Attractive aspects of CsA treatment are its effect in the initial stages of the immune response over $\mathrm{T}$ cell function, suppression of intraocular inflammation within a period as short as 1-2 weeks in 44 to $50 \%$ of patients and the increase or stability of visual acuity of patients in $70-91 \%{ }^{(23-25)}$. The most relevant side effects of cyclosporine are dose-dependent nephrotoxicity and hypertension; however, several studies have revealed that low-dose of CsA $(5 \mathrm{mg} / \mathrm{kg} /$ day) combined with steroids can be as effective as highdose of CsA ( $10 \mathrm{mg} / \mathrm{kg} / \mathrm{day})$ alone in reducing the frequency and severity of attacks with a lower incidence of significant renal side effects ${ }^{(24)}$. In spite of these attractive aspects, CsA effects are directly dose-related and only persist for as long as it is being administered ${ }^{(23)}$. In the present study, CsA was effective in reducing ocular attacks and prednisone dose in $57 \%$ of eyes, similar to the literature $^{(24)}$. Reactivation of the ocular inflammation after discontinuing or reducing the dose of CsA was observed in 5 out 14 patients $(35.7 \%)$, reinforcing its non-tolerogenic effect $^{(23,26)}$. Although low-dose CsA is reported to generate fewer side effects, $57 \%$ of patients had to discontinue the drug over time due to intolerable side effects.

Systemic immunosuppressants in Behçet's disease uveitis has improved visual prognosis. In the past, blindness was observed in $90 \%$ of untreated patients followed up for a mean period of 3.6 years $^{(7)}$ and in as many as $74 \%$ of the eyes during the first 6 to 10 years after the onset of the ocular symptoms, regardless of the type of treatment ${ }^{(27)}$. More recent investigations show a downward trend in the prevalence of blindness among patients with ocular involvement due to Behçet's disease ${ }^{(4-6)}$, attributed to the use of immunosuppressants. In the present study, systemic immunosuppressants in ocular Behçet's disease resulted in good clinical outcomes, as only $13.6 \%$ of patients with initial visual acuity better than 0.1 dropped below this threshold after a median follow up of 11 years (range 1-29).

\section{CONCLUSION}

The current study demonstrated that chlorambucil, although abandoned by the majority of specialists, was efficient in controlling ocular inflammatory activity as well as in inducing remission in Behçet disease patients. This drug may still be an option in patients with intractable and sigh-threatening uveitis. Cyclosporine A is still the current first line of therapy since it is effective in controlling inflammation, has been used in the last three decades with success, and, in spite of not inducing disease remission and having frequent side effects with long-term use, its side effects are reversible. Ideally novel treatments should induce disease remission devoid of side effects.

\section{ACKNOWLEDGMENTS}

The authors acknowledge Dr. Maria Lucia Marin for HLA typification. The authors also acknowledge Dr. Rogerio Ruscitto do Prado, Statistics, Department of Preventive Medicine, University of São Paulo School of Medicine, São Paulo, Brazil for his assistance in statistical analysis.

\section{RESUMO}

Objetivos: Avaliar a eficácia e efeitos colaterais da terapia imunossupressora em pacientes com uveíte associada à doença de Behçet. Métodos: Estudo retrospectivo não randomizado no qual são analisados dados de 22 pacientes com uveíte associada à doença de Behçet que utilizaram clorambucil e/ou ciclosporina A sistêmica por período mínimo de 6 meses, acompanhados pelo período mínimo de 1 ano, num único Serviço de Uveíte, São Paulo, Brasil (período 1978-2007). A eficácia do tratamento foi avaliada pela redução no número de recidivas da inflamação e pela redução na dose diária de prednisona. Resultados: Vinte e dois pacientes (10 M/12 F), com idade média de 29 (variação 10-43) anos, apresentaram tempo mediano de acompanhamento de 11 (variação 1-29) anos. Clorambucil (2-6 mg/dia) foi utilizado em 13 pacientes e ciclosporina A (3-5 mg/kg/dia) em 9 pacientes como droga de primeira escolha. As drogas foram substituídas quando não eficazes ou não toleradas devido a efeitos colaterais. Clorambucil foi eficaz em 78,5\% (11/14) e induziu remissão da doença em $43 \%$ (6/14) dos pacientes; ciclosporina foi eficaz em $57 \%$ (8/14) dos pacientes. Clorambucil e ciclosporina A foram suspensos devido a efeitos colaterais em $21 \%$ (leucopenia) e em $57 \%$ (nefrotoxicidade, $36 \%$ e complicações gastrointestinais, $21 \%$ ) dos pacientes, respectivamente. Nenhum caso de malignidade foi observado. 36\% (16/44) olhos tiveram acuidade visual final $\leq 0,1$, sendo que $69 \%(11 / 16)$ já apresentavam esta acuidade na primeira consulta. Conclusão: Este estudo reforça dados de literatura que o clorambucil induz remissão da doença de Behçet enquanto a ciclosporina A é efetiva, porém efeitos colaterais limitam o seu uso. A terapia com clorambucil pode ser uma opção a ser considerada em pacientes com uveíte refratária associada à doença de Behçet.

Descritores: Síndrome de Behçet; Imunossupressores; Clorambucil/uso terapêutico; Ciclosporina/uso terapêutico; Uveíte/terapia; Estudos retrospectivos 


\section{REFERENCES}

1. Evereklioglu C. Current concepts in the etiology and treatment of Behçet's disease. Surv Ophthalmol. 2005;50(4):297-350. Comment in: Surv Ophthalmol. 2006;51(2):174; author reply 174-7.

2. Gouveia EB, Yamamoto JH, Abdalla M, Hirata CE, Kubo P, Olivalves E. Causas das uveítes em serviço terciário em São Paulo, Brasil. Arq Bras Oftalmol. 2004;67(1):139-45.

3. Ohno S, Ohbuchi M, Hirose S, Matsuda H, Wakisaka A, Aizawa M. Close association of HLA-Bw51 with Behçet's disease. Arch Ophthalmol. 1982; 100(9):1455-8

4. Ando K, Fujino Y, Hijikata K, Izawa Y, Masuda K. Epidemiological features and visual prognosis of Behçet's disease. Jpn J Ophthalmol. 1999;43(4):312-7.

5. Sakamoto M, Akazawa K, Nishioka Y, Sanui H, Inomata H, Nose Y. Prognostic factors of vision in patients with Behçet's disease. Ophthalmology. 1995; 102(2):317-21. Comment in: Ophthalmology. 1995;102(12):1739.

6. Tugal-Tutkun I, Onal S, Altan-Yaycioglu R, Huseyin Altunbas H, Urgancioglu M. Uveitis in Behçet's disease: an analysis of 880 patients. Am J Ophthalmol. 2004;138(3):373-80.

7. Mamo JG. The rate of visual loss in Behçet's disease. Arch Ophthalmol. 1970; 84(4):451-2.

8. Abdalla MI, El-D Bahoat N. Long-lasting remission of Behçet's disease after chlorambucil therapy. Br J Ophthalmol. 1973;57(9):706-11.

9. Patapanian H, Graham S, Sambrook PN, Browne CD, Champion GD, Cohen $\mathrm{ML}$, et al. The oncogenicity of chlorambucil in rheumatoid arthritis. $\mathrm{Br} \mathrm{J}$ Rheumatol. 1988;27(1):44-7.

10. Nussenblatt RB, Palestine AG, Rook AH, Scher I, Wacker WB, Gery I. Treatment of intraocular inflammatory disease with cyclosporin A. Lancet. 1983;2(8344):235-8.

11. Masuda K, Nakajima A, Urayama A, Nakae K, Kogure M, Inaba G. Doublemasked trial of cyclosporin versus colchicine and long-term open study of cyclosporin in Behçet's disease. Lancet. 1989;1(8647):1093-6.

12. Goldstein DA, Fontanilla FA, Kaul S, Sahin O, Tessler HH. Long-term follow-up of patients treated with short-term high-dose chlorambucil for sightthreatening ocular inflammation. Ophthalmology. 2002;109(2):370-7.

13. Skin hypersensitivity to streptococcal antigens and the induction of systemic symptoms by the antigens in Behçet's disease- a multicenter study. The Behçet's Disease Research Committee of Japan. J Rheumatol. 1989;16(4): 506-11.
14. Doycheva D, Deuter C, Stuebiger N, Biester S, Zierhut M. Mycophenolate mofetil in the treatment of uveitis in children. Br J Ophthalmol. 2007;91(2): 180-4. Comment in: Br J Ophthalmol. 2007;91(2):133-4.

15. Marin ML, Savioli CR, Yamamoto JH, Kalil J, Goldberg AC. MICA polymorphism in a sample of the São Paulo population, Brazil. Eur J Immunogenet. 2004;31(2):63-71.

16. Jabs DA, Nussenblatt RB, Rosenbaum JT; Standardization of Uveitis Nomenclature (SUN) Working Group. Standardization of uveitis nomenclature for reporting clinical data. Results of the First International Workshop. Am J Ophthalmol. 2005;140(3):509-16.

17. Benezra D, Cohen E. Treatment and visual prognosis in Behçet's disease. Br J Ophthalmol. 1986;70(8):589-92.

18. Tricoulis D. Treatment of Behçet's disease with chlorambucil. Br J Ophthalmol. 1976;60(1):55-7.

19. Tabbara KF. Chlorambucil in Behçet's disease. A reappraisal. Ophthalmology. 1983;90(8):906-8.

20. Jabs DA, Rosenbaum JT, Foster CS, Holland GN, Jaffe GJ, Louie JS, et al. Guidelines for the use of immunosuppressive drugs in patients with ocular inflammatory disorders: recommendations of an expert panel. Am J Ophthalmol. 2000;130(4):492-513. Comment in: Am J Ophthalmol. 2001;131(5):679.

21. Kempen JH, Gangaputra S, Daniel E, Levy-Clarke GA, Nussenblatt RB, Rosenbaum JT, et al. Long-term risk of malignancy among patients treated with immunosuppressive agents for ocular inflammation: a critical assessment of the evidence. Am J Ophthalmol. 2008;146(6):802-12.

22. Miserocchi E, Baltatzis S, Ekong A, Roque M, Foster CS. Efficacy and safety of chlorambucil in intractable noninfectious uveitis: the Massachusetts Eye and Ear Infirmary experience. Ophthalmology. 2002;109(1):137-42.

23. Müftüoðlu AU, Pazarli H, Yurdakul S, Yazici H, Ulkü BY, Tüzüun Y, et al. Short term cyclosporin A treatment of Behçet's disease. Br J Ophthalmol. 1987;71:387-90.

24. Süllü Y, Öge I, Erkan D, Aritürk N, Mohajeri F. Cyclosporin-A therapy in severe uveitis of Behçet's disease. Acta Ophthalmol Scand. 1998;76(1):96-9.

25. Atmaca LS, Batioglu F. The efficacy of cyclosporin-A in the treatment of Behçet's disease. Ophthalmic Surg. 1994;25(5):321-7.

26. Hemady R, Tauber J, Foster CS. Immunosuppressive drugs in immune and inflammatory ocular disease. Surv Ophthalmol. 1991;35(5):369-85. Erratum in: Surv Ophthalmol. 1991;35(6):475. Dosage error in article text.

27. Kitaichi N, Miyazaki A, Iwata D, Ohno S, Stanford MR, Chams H. Ocular features of Behçet's disease: an international collaborative study. Br J Ophthalmol. 2007;91(12):1579-82. Comment in: Br J Ophthalmol. 2007;91(12):1573-4.

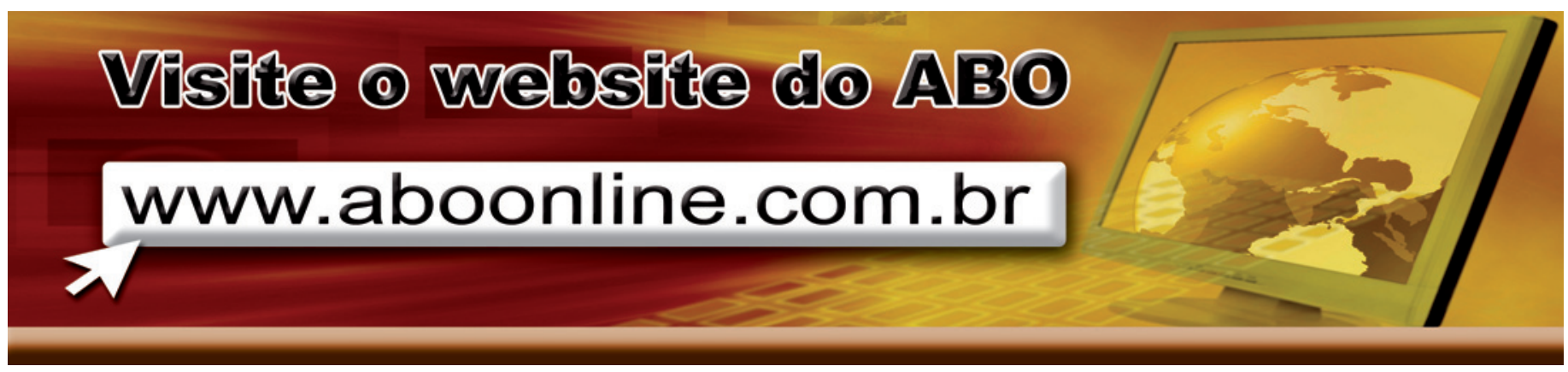

